\title{
Urgensi Transformasi Pelayanan Publik melalui E-Government Pada New Normal dan Reformasi Regulasi Birokrasi
}

\author{
Anggita Doramia Lumbanraja \\ Fakultas Hukum, Universitas Diponegoro \\ Jalan Prof. Soedarto, S.H., Tembalang, Semarang \\ anggitalumbanraja@live.undip.ac.id
}

\begin{abstract}
Covid-19 pandemic has a significant impact on society in Indonesia. New Normal discourse will be applied soon in Indonesia. Basically, it will give the same restriction and limitation of the interaction between individuals. Before pandemic, Conventional Public services required direct interaction between citizens and public servants in public office. But then, there will be a limitation to this direct interaction, and it also has to switch into the online services model. This study examined the urgency of the transformation of public services during the New Normal period through E-Government. This research used the normative juridical method. The author finds that the use of e-government in Indonesia is still far below Singapore. Indonesia needs to optimize the use of vertical and horizontal integration models that present one-stop service network services that require the transformation of public services from the Old Public Administration model to the New Public Service. This transformation should also be supported by regulatory reforms in the field of State Administration to increase synergy and harmonization between government institutions, so there is no overlapping of authority and conflicts between institutions that can hinder service delivery to the public.
\end{abstract}

\section{Keywords : Transformation of Government Services; E-Government; New Normal}

\begin{abstract}
Abstrak
Pandemi Covid-19 membawa dampak yang besar bagi masyarakat di Indonesia. Wacana New Normal yang akan diberlakukan, secara garis besar tetap membatasi interaksi antar individu. Pelayanan publik yang selama ini dilakukan dengan beinteraksi secara langsung harus dibatasi bahkan harus beralih kepada pelayanan secara online. Penelitian ini hendak mengkaji urgensi transformasi pelayanan publik pada masa New Normal melalui E-Government. Penelitian ini menggunakan metode yuridis normatif. Penulis menemukan bahwa penggunaan e-government di Indonesia masih jauh di bawah negara Singapura. Indonesia perlu mengoptimalkan penggunaan model integrasi vertikal dan integrasi horizontal yang menghadirkan network service layanan satu pintu yang membutuhkan transformasi pelayanan publik dari model Old Administration Public menuju New Public Service. Hal ini perlu juga ditunjang dengan adanya reformasi regulasi di bidang Administrasi Negara untuk meningkatkan sinergitas dan harmonisasi antar lembaga pemerintah, agar tidak terjadi tumpang tindih kewenangan dan konflik antar lembaga yang dapat menghambat pemberian layanan kepada masyarakat.
\end{abstract}

Kata Kunci : Transformasi Pelayanan Publik; E-Government; New Normal 


\section{Administrative Law \& Governance Journal. Volume 3 Issue 2, June 2020 ISSN. 2621-2781 Online}

\section{A. Pendahuluan}

Pandemi Coronavirus Disease 2019 (COVID-19) mewabah ke seluruh dunia sejak awal tahun 2020 dan membawa dampak yang signifikan bagi kehidupan manusia di seluruh dunia. Kebijakan pemberlakuan Lockdown (Karantina Wilayah) dan Social Distancing (Pembatasan Sosial) diberlakukan oleh negara-negara di dunia yang terkena dampak pandemi COVID-19. Pemberlakuan kebijakan tersebut menyebabkan masyarakat tidak dapat berinteraksi secara langsung satu sama lain. Hal ini bertujuan untuk mengurangi resiko penularan COVID-19 yang sangat mudah menular antar satu orang ke orang lain. Pembatasan interaksi tersebut menyebabkan masyarakat dalam memenuhi kebutuhannya tidak dapat mempertahankan caracara konvensional untuk memperoleh atau memenuhi kebutuhannya. Masyarakat mau tidak mau harus beralih kepada penggunaan media online.

Sejak dikeluarkannya PP Nomor 21 Tahun 2020 tentang Pembatasan Sosial Berskala Besar Dalam Rangka Percepatan Penanganan Corona Virus Disease (COVID-19) pada tanggal 31 Maret 2020, beberapa wilayah di tanah air memberlakukan PSBB (Pembatasan Sosial Berskala Besar) yang menyebabkan sekolah dan tempat kerja diliburkan, kegiatan keagamaan atau ibadah bersama dibatasi dan kegiatan-kegiatan di tempat umum atau fasilitas publik juga dibatasi. Hal ini untuk menghindari terjadinya kerumunan banyak orang agar resiko penularan virus ini dapat ditekan. Pemberlakuan Pembatasan Sosial di Indonesia juga membawa dampak pada aksesibilitas pelayanan publik. Surat Edaran yang dikeluarkan oleh Menteri Pendayagunaan Aparatur Negara dan Reformasi Birokrasi (PANRB) Nomor 19 Tahun 2020 tentang Penyesuaian Sistem Kerja Aparatur Sipil Negara Dalam Upaya Pencegahan Penyebaran COVID-19 Di Lingkungan Instasi Pemerintah. Surat Edaran ini memberlakukan work from home (bekerja di rumah) secara bergantian bagi para pegawai di Lingkungan Instansi Pemerintah. Hal ini mempengaruhi aksesibiltas pelayanan publik. Pelayanan secara konvensional yakni dengan bertatap muka secara langsung mulai dibatasi jumlahnya dan selebihnya dibantu oleh sistem secara online. Pelayanan secara online ini merupakan hasil penerapan dari E-Government.

Menurut Rachel Silcock E-Government adalah penggunaan teknologi untuk meningkatkan akses dan pengiriman layanan pemerintah untuk memberi manfaat bagi warga negara, mitra bisnis, dan karyawan. E-Government terus mendorong untuk berinovasi dan 


\section{Administrative Law \& Governance Journal. Volume 3 Issue 2, June $2020 \mid$ ISSN. 2621-2781 Online}

menciptakan, mengembangkan mode layanan publik baru di mana semua organisasi publik dan instansi pemerintah memberikan layanan yang modern, terintegrasi, dan tanpa batas bagi warganya. Hubungan antara masyarakat dengan pemerintah bukanlah lagi searah yakni topdown melainkan membangun kemitraan antara pemerintah dan warga negara (Silcock, 2001).

Pendapat Silcock selaras dengan pendapat dari McClure yang mengemukakan bahwa $E$ Government merupakan penggunaan teknologi oleh pemerintah, khususnya aplikasi berbasis web via internet (web-based internet application) untuk meningkatkan akses dan pengiriman informasi pemerintah dan layanan kepada warga negara, mitra bisnis, karyawan, lembaga lain, dan entitas pemerintah. E-Government memiliki potensi untuk membantu membangun hubungan yang lebih baik antara pemerintah dan publik oleh membuat interaksi dengan warga lebih lancar, lebih mudah, dan lebih efisien (McClure, 2000)

Sedangkan menurut Zhiyuan Fang, E-Government didefinisikan sebagai cara untuk pemerintah menggunakan teknologi informasi dan komunikasi yang inovatif, khususnya aplikasi berbasis web via internet (web-based internet application), untuk menyediakan akses informasi dan layanan pemerintah yang lebih mudah bagi warga negara. Hal ini dilakukan demi meningkatkan kualitas layanan dan memberikan peluang lebih besar bagi masyarakat untuk berpartisipasi dalam pembangunan institusi pemerintah dan proses demokrasi (Fang, 2002).

Karen Layne dan Jungwoo Lee mengemukakan dalam peneltiiannya bahwa ada empat model pertumbuhan e-government yakni : (1) cataloguing (katalogisasi), (2) transaction (transaksional), (3) vertical integration (integrasi vertikal lembaga-lembaga dalam jenjang hirarkis), (4) horizontal integration (integrasi horizontal antar lembaga dalam satu jajaran). Lebih jauh digambarkan oleh Karen Layne dan Jungwoo Lee mengenai dimensi dan tingkatan pengembangan e-government yang diilustrasikan dalam Gambar 1 (Layne \& Lee, 2001). 


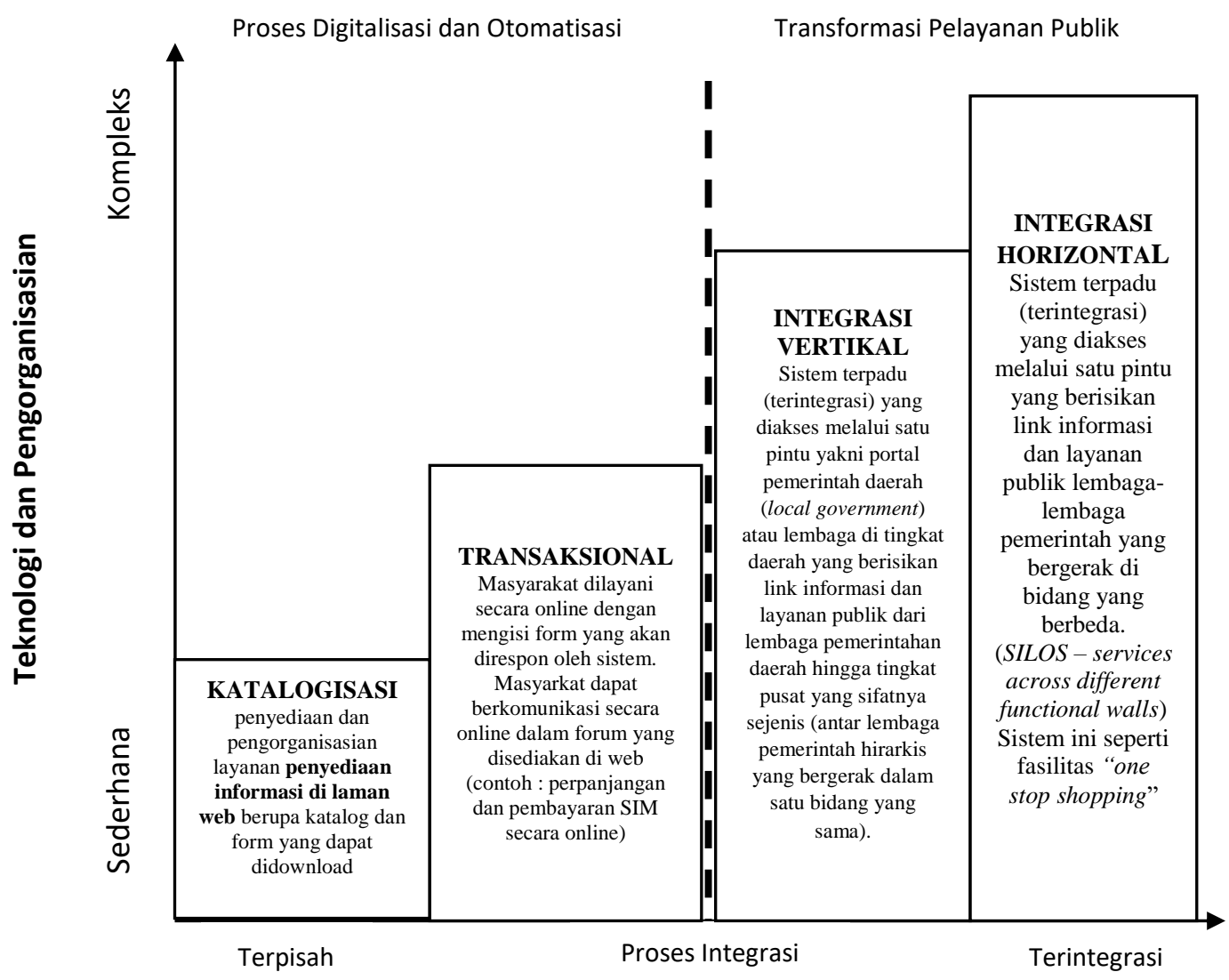

Gambar 1. Dimensi dan Tingkatan Pengembangan E-Government menurut Karen Layne dan Jungwoo Lee (Layne \& Lee, 2001)

Banyak penelitian sebelumnya yang telah mengkaji mengenai e-government di Indonesia. Di antaranya penelitian yang dilakukan oleh Ali Rokhman menganalisa tentang regulasi dan pengimplementasian e-governmenti oleh Pemerintah Daerah, dan sejauh mana perkembangan terhadap sistem e-government yang dilakukan oleh Pemerintah Daerah tersebut (Himawan, 2012). Pada tahun 2011, dalam publikasinya, Budi Hermana dan Widya Silfianti mengevaluasi penerapan e-government oleh antar pemerintah daerah di Indonesia dengan mengacu pada web metrics rank dan membedakan datanya berdasarkan pemerintah daerah yang berada di Pulau Jawa dan di Luar Pulau Jawa (Hermana \& Silfianti, 2011). 
Pada tahun 2020, Deborah Agostino, et.al, mengemukakan bahwa pandemi COVID-19 membawa dampak bagi perkembangan transformasi digital dalam pemberian layanan publik di Italia. Tantangan-tantangan sosial yang muncul pasca merebaknya pandemic COVID-19 memaksa lembaga-lembaga publik atau institusi pemerintah untuk melakukan akselerasi digital untuk mengoptimalisasi layanan publik (Agostino, Arnaboldi, \& Lema, 2020). Dari ketiga penelitian di atas dan berdasarkan penelusuran yang dilakukan oleh Penulis, belum ada penelitian yang meneliti tentang urgensi penerapan e-government dan reformasi regulasi birokrasi saat New Normal diberlakukan.

Wacana pemberlakukan New Normal memaksa masyarakat di Indonesia untuk dapat beraktivitas kembali di luar rumah, berdampingan dengan resiko wabah COVID-19. Oleh karena itu New Normal memiliki karakter yang berbeda dengan situasi normal sebelum pandemi COVID-19 merebak. Protokol Kesehatan untuk mencegah penyebaran virus tetap diberlakukan dan terus digalakkan pada setiap prosedur pelayanan masyarakat. Sehingga bisa dipastikan pelayanan publik secara konvensional pada saat situasi normal sebelum pandemi tidak dimungkinkan untuk diterapkan pada New Normal. Hal ini memunculkan urgensi terhadap penerapan dan akselerasi pengembangan e-government oleh instansi-intansi pemerintah.

Penelitian ini yang berjudul "Urgensi Transformasi Pelayanan Publik melalui EGovernment Pada New Normal dan Reformasi Regulasi Birokrasi" mengkaji tentang seberapa jauh urgensi pemberlakuan transformasi pelayanan public melalui e-government pada saat New Normal diberlakukan dan seberapa perlunya memberlakukan reformasi regulasi birokrasi untuk mengoptimalisasi layanan publik melalui e-government.

\section{B. Metode Penelitian}

Penelitian ini menggunakan metode yuridis normatif dengan melakukan studi kepustakaan. Penulis mengumpulkan data sekunder berupa bahan-bahan hukum primer berupa peraturan perundang-undangan dan bahan-bahan hukum sekunder berupa, artikel, buku dan jurnal pada bidang Hukum Administrasi Negara dan Hukum Tata Negara yang berhubungan dengan pelayanan publik khususnya mengenai e-government. 


\section{B. Hasil dan Pembahasan}

\section{Urgensi Transformasi Pelayanan Publik melalui E-Government Pada New Normal}

Pada tanggal 9 Juni 2003, Presiden Megawati Soekarnoputri mengeluarkan Instruksi Presiden Nomor 3 Tahun 2003 tentang Kebijakan dan Strategi Nasional Pengembangan EGovernment. Secara normatif, Instruksi Presiden tersebut mengawali pengembangan $E$ Government di Indonesia. Pada tahun 2018 Indonesia menempati posisi 107 pada World EGovernment Development Ranking yang dikeluarkan oleh lembaga PBB (Persatuan BangsaBangsa) (United Nations, 2018).

Tabel 1. World E-Government Development Ranking - United Nations

\begin{tabular}{|c|c|c|c|c|c|c|c|c|c|}
\hline & \multirow[b]{2}{*}{ Negara } & \multicolumn{8}{|c|}{ World E-Government Development Ranking } \\
\hline & & 2008* & 2010 $* *$ & $2012 * * * *$ & $2014 * * * * *$ & 2016 ******* & 2018 ******** & $\begin{array}{c}\text { Rata-Rata } \\
\text { peringkat 2008- } \\
2018\end{array}$ & $\begin{array}{c}\text { Kenaikan } \\
\text { atau } \\
\text { Penurunan } \\
\text { Peringkat } \\
(2008 \text { - 2018) }\end{array}$ \\
\hline 1 & Singapura & 23 & 11 & 10 & 3 & 4 & 7 & $10(3-23)$ & +16 \\
\hline 2 & Malaysia & 34 & 32 & 40 & 52 & 60 & 48 & $44(32-60)$ & -14 \\
\hline 3 & $\begin{array}{l}\text { Brunei } \\
\text { Darussalam }\end{array}$ & 87 & 68 & 54 & 86 & 83 & 59 & $60(54-87)$ & +28 \\
\hline 4 & Thailand & 64 & 76 & 92 & 102 & 77 & 73 & $81(64-102)$ & -9 \\
\hline 5 & Filipina & 66 & 78 & 88 & 95 & 71 & 75 & $79(66-95)$ & -9 \\
\hline 6 & Vietnam & 91 & 90 & 83 & 99 & 89 & 88 & $90(83-99)$ & +3 \\
\hline 7 & Indonesia & 106 & 109 & 97 & 106 & 114 & 92 & $104(92-114)$ & +14 \\
\hline 8 & Timor Leste & 155 & 162 & 170 & 161 & 160 & 142 & $\begin{array}{c}159(142- \\
170)\end{array}$ & +13 \\
\hline 9 & Kamboja & 139 & 140 & 155 & 139 & 158 & 145 & $\begin{array}{c}146(139- \\
158)\end{array}$ & -6 \\
\hline 10 & Myanmar & 144 & 141 & 160 & 175 & 169 & 157 & $\begin{array}{c}158(144- \\
175)\end{array}$ & -13 \\
\hline 11 & Laos & 156 & 151 & 153 & 152 & 148 & 162 & $\begin{array}{c}154(148- \\
162)\end{array}$ & -6 \\
\hline
\end{tabular}

*(United Nations, 2008), **(United Nations, 2010), ***(United Nations, 2012), *****(United Nations, 2014), *nswat(United Nations, 2016), 
Dari tabel 1. dapat dilihat bahwa Indonesia berada di urutan ke tujuh di antara 11 negaranegara Asia Tenggara. Sejak tahun 2003, Indonesia mengalami kenaikan dan penurunan peringkat, dan di tahun 2008 Indonesia berhasil berada di posisi 92 pada rangking $E$ Government Development dari 193 negara anggota PBB.

Berdasarkan data PBB di tahun 2014, Indonesia tercatat telah menerapkan 4 model pelayanan publik secara online, dengan presentasi penggunaan sebagaimana disebutkan di dalam Tabel 2.

Tabel 2. Pelayanan public berbasis elektronik di Indonesia berdasarkan stages atau model tahapan $e$ government (United Nations, 2018)

\begin{tabular}{cccc}
\hline Stage 1 & Stage 2 & Stage 3 & Total \\
\hline $66,67 \%$ & $73,91 \%$ & $45,45 \%$ & $63,04 \%$ \\
\hline
\end{tabular}

Apabila kita bandingkan dengan presentase pelayanan publik berbasis elektronik di Singapura di tahun 2012 pada tabel 3, maka terlihat jelas perbedaannya.

Tabel 3. Pelayanan public berbasis elektronik di Singapura berdasarkan stages atau model tahapan $e$ government (United Nations, 2018)

\begin{tabular}{cccc}
\hline Stage 1 & Stage 2 & Stage 3 & Total \\
\hline $100 \%$ & $91,30 \%$ & $100 \%$ & $96,74 \%$ \\
\hline
\end{tabular}

Berdasarkan Tabel 2 dan Tabel 3 dapat kita lihat bahwa penyebab jauhnya peringkat yang diperoleh Indonesia dibandingkan Singapura yang selalu menduduki peringkat 10 besar berdasarkan survey yang dilakukan PBB tersebut, adalah karena masih jauhnya penggunaan pemberian layanan publik berbasis elektronik di Indonesia yang penggunaannya masih di angka 63,04\% sedangkan Singapura telah berada di angka 96,74\% yang sudah hampir menyentuh angka $100 \%$. Berdasarkan tabel 2, maka Indonesia harus meningkatkan performa di stage 3 yakni network services yang didapat dari model integrasi vertikal dan integrasi horizontal. Pelayanan publik berbasis elektronik satu pintu masih kurang optimal di Indonesia. Dari 33 pemerintah daerah di Indonesia, sistem terpadu e-government yang paling kompleks adalah pemerintah daerah di Pulau Jawa seperti Surabaya, Bandung dan Jakarta. Hal ini menjadi 


\section{Administrative Law \& Governance Journal. Volume 3 Issue 2, June 2020 ISSN. 2621-2781 Online}

pekerjaan rumah bagi Pemerintah Pusat untuk mendorong instansi di daerah agar mengoptimalkan dan mengembangkan sistem e-government di daerahnya.

Selama dua dekade ini, Indonesia telah mengalami perubahan sosial yang cukup besar. Nilai-nilai yang ada di dalam masyarakat perlahan mulai bergeser dari nilai tradisional menuju modern. Hal ini perlu direspon dengan perubahan pada tubuh birokrasi institusi pemerintah yang memberikan pelayanan public kepada masyarakat. Perlu adanya perubahan perspektif Administrasi, meninggalkan Perspektif Old Public Administration menuju Perspektif New Public Service. Janet dan Robert Denhardt (Denhardt \& Denhardt, 2003) mengemukakan bahwa ada 7 karakter dari prinsip New Public Service yakni :

1. Peran utama pelayan publik (Aparatur Sipil Negara/ASN) adalah untuk membantu masyarakat memenuhi kepentingan dan kebutuhan mereka, bukan berarti mengendalikan atau mengarahkan masyarakat ke arah yang baru

2. Para Administrator Publik sepakat terhadap gagasan bahwa kepentingan publik adalah yang terpenting

3. Kebijakan dan program-program pemerintah haruslah dapat memenuhi kebutuhan masyarakat dengan upaya-upaya kolektif dan proses kolaboratif agar lebih efektif dan responsif.

4. Kepentingan publik merupakan hasil dialektika nilai-nilai bersama daripada kepentingan pribadi/individu

5. Pelayan publik (ASN) wajib menjunjung tinggi moral, peraturan perundangundangan yang berlaku, hukum konstitusi, nilai-nilai sosial, norma politik, standar professional dan kepentingan masyarakat.

6. Organisasi Pemerintah dan para pemangku kepentingan bekerja sama dalam proses kolaborasi (processes of collaboration) dan kepemimpinan bersama (shared leadership)

7. Kepentingan publik sebaiknya dilayani oleh Pelayan Publik (ASN) dan masyarakat secara bersama-sama daripada dilakukan oleh pihak swasta yang bertindak seolah-olah uang publik adalah uang mereka sendiri

Berdasarkan ke tujuh prinsip New Public Service tersebut maka dapat dilihat bahwa perlu adanya reformasi secara politik, manajemen dan terutama mental para birokrat. Jika tidak 
diimbangi dengan ini maka, sulit menerapkan transformasi pelayanan publik berbasis $e$ government. Karena pengembangan dan pengoptimalisasian e-government membutuhkan perubahan perspektif Pejabat Administrasi Negara dari Old Public Administration menuju New Public Services.

Dari Tabel 2 mengindikasikan bahwa Kerjasama antar instansi pemerintah masih sangat kurang. Sinergisme dan koordinasi antar lembaga pemerintah masih sangat minim. Hal ini membuat pelayanan publik berbasis e-government di Indonesia masih jauh tertinggal dari negara-negara maju yang telah berhasil menerapkan publik publik terintegrasi satu pintu. Proses kolaboratif dan kepemimpinan bersama masih kerap diabaikan karena ego sektoral.

Pada masa New Normal nanti, sinergitas dan koordinasi antar lembaga sangatlah dibutuhkan. Akses masyarakat ke kantor-kantor institusi pemerintah akan dibatasi dan mempersulit mereka dalam mengakses pelayanan publik. Apabila pelayanan secara konvensional tidak dialihkan kepada pelayanan berbasis elektronik secara terpadu, maka hal tersebut akan merugikan masyarakat. Para pemangku kepentingan harus merombak dan mengoptimalisasikan model integrasi vertikal dan integrasi horizontal untuk membantu masyarakat mengakses layanan publik pada masa New Normal, tanpa harus mengunjungi kantor instansi pemerintah.

\section{Urgensi Reformasi Regulasi Birokrasi Untuk Mendorong Upaya Optimalisasi}

\section{Penerapan E-Government pada New Normal}

Indonesia telah mengeluarkan beberapa peraturan perundang-undangan terkait penerapan E-Government yakni sebagai berikut

a) Pasal 28 F Undang-Undang Dasar Tahun 1945

b) Undang-Undang Nomor 11 Tahun 2008 tentang Kebijakan dan Strategi Nasional Pengembangan E-Government

c) Undang-Undang Nomor 14 Tahun 2008 tentang Keterbukaan Informasi Publik

d) PP Nomor 82 Tahun 2012 tentang Penyelenggaraan Sistem dan Transaksi Elektronik

e) Instruksi Presiden 3 Tahun 2003 tentang Kebijakan dan Strategi Nasional Pengembangan E-Government 


\section{Administrative Law \& Governance Journal. Volume 3 Issue 2, June 2020 ISSN. 2621-2781 Online}

Selain kelima peraturan di atas, di jajaran pemerintah daerah, juga mengeluarkan PERDA yang mengatur secara Teknis mengenai penerapan e-government di lembaganya. Berdasarkan penelusuran oleh Penulis, ada beberapa pemerintahan daerah yang telah menerapkan network service yang mengimplementasikan integrasi vertikal dan integrasi horizontal. Namun karena kebijakan makro dari pemerintah pusat hanya dapat ditemui di INPRES Nomor 3 Tahun 2003, maka pengaturan mengenai e-government masih minim. UU Keterbukaan Informasi Publik masih menekankan pada penerapan model Katalogisasi (Emergence and Interactive Presence Service) dan Transaksional (Transactional Presence Service).

Untuk dapat mengoptimalkan penerapan e-government di masa New Normal, maka Indonesia harus mengeluarkan beberapa peraturan di tingkat teknis seperti Peraturan Pemerintah yang mengatur mengenai sinergitas, kolaborasi dan kepemimpinan bersama antar lembaga pemerintah. Sudah saatnya, peraturan yang dikeluarkan pemerintah haruslah lebih kompleks yang mengatur Kerjasama antar lembaga agar tidak tumpang tindih namun saling bersinergi.

Wacana Omnibus Law yang sampai detik ini masih memicu pro dan kontra, sebenarnya sangat cocok diterapkan apabila mengoptimalisasikan public services berbasis elektonik. Pengaturan lintas sektor sangat diperlukan untuk memotong birokrasi dan mendukung pelayanan satu pintu. Integrasi vertikal dan integrasi horizontal dapat diatur dalam Omnibus Law.

\section{Simpulan}

Indonesia masih perlu meningkatkan penggunaan e-government terutama mengoptimalisasikan penerapan model Network Service. Hal ini menjadi urgen manakala kita akan menghadapi pemberlakuan New Normal. Apabila tidak segera ditingkatkan maka akan merugikan Masyarakat dalam mengakses layanan publik. Oleh karena itu perlunya perubahan perspektif Old Public Administration menuju New Public Services yang menuntut adanya proses kolaborasi (processes of collaboration) dan kepemimpinan bersama (shared leadership).

Untuk dapat menerapkan hal tersebut maka perlu adanya reformasi regulasi di bidang birokrasi. Wacana Omnibus Law sebenarnya dapat menstimulasi pengoptimlasisasian penerapan e-government di Indonesia terutama penerapan model Network Serivce yang 
menuntut integrasi vertikal dan integrasi horizontal. Pengaturan lintas sektor sangat diperlukan untuk pembangunan e-government di Indonesia

\section{Daftar Pustaka}

McClure, D. L. (2000). Statement of David L. McClure, U.S. General Accounting Office, before the Subcommittee on Government Management, Information and Technology, Committee on Government Reform, House of Representatives. Available: http://www.gao.gov.

Denhardt, Janet, V., \& Denhardt, Robert B. (2003). The New Public Service. Armonk, New York : M.E. Sharpe.

Agostino, Deborah., Arnaboldi, Michela., \& Lema, Melisa Diaz. (2012). Public Money and Management, pp 1-4 https://doi.org/10.1080/09540962.2020.1764206

Fang, Zhiyuan. (2002). E-Government in Digital Era : Concept, Practice, and Development. International Journal of The Computer, The Internet and Management, Vol 10, No 2, pp 1-22.

Hermana, Budi, \& Silfianti, Widya. (2011). Evaluating E-Government Implementation by Local Government : Digital Divide in Internet Based Public Services in Indonesia. International Journal of Business and Social Science, Vol 2, No 3, pp 156-163

Himawan, Hidayatulah. (2012). Implementasi Dan Analisa Regulasi Pemerintah Daerah Dalam Mendukung Perkembangan E-Government. Seminar Nasional Informatika (SEMNASIF), Vol 1, No 4

Layne, Karen, \& Lee, Jungwoo. (2001). Developing Fully Functional E-Government : A Four Stage Model. Government Information Quarterly, Vol 18, Issue 2, pp 122-136. https://doi.org/10.1016/S0740-624X(01)00066-1

Silcock, Rachel. (2001). What is E-Government?. Parliamentary Affairs, Vol 54, Issue 1, pp 88-101. https://doi.org/10.1093/pa/54.1.88

United Nations. (2008). UN E-Government Survey 2008: From E-Government to Connected Governance. New York: United Nations Publication

United Nations. (2010). UN E-Government Survey 2010: Leveraging E-Government at a Time of Financial and Economic Crisis. New York: United Nations Publication

United Nations. (2012). UN E-Government Survey 2012: E-Government for The People. New York: United Nations Publication

United Nations. (2014). UN E-Government Survey 2014: E-Government For The Future We Want. New York: United Nations Publication

United Nations. (2016). UN E-Government Survey 2016: E-Government for Sustainable Development. New York: United Nations Publication 
Administrative Law \& Governance Journal. Volume 3 Issue 2, June 2020 ISSN. 2621-2781 Online

United Nations. (2018). UN E-Government Survey 2018 : FromGearing E-Government to Support Transformation Towards Sustainable and Resilient Societies. New York : United Nations Publication

Undang-Undang Dasar Republik Indonesia Tahun 1945

Undang-Undang Nomor 11 Tahun 2008 tentang Kebijakan dan Strategi Nasional Pengembangan E-Government

Undang-Undang Nomor 14 Tahun 2008 tentang Keterbukaan Informasi Publik

PP Nomor 82 Tahun 2012 tentang Penyelenggaraan Sistem dan Transaksi Elektronik

Instruksi Presiden 3 Tahun 2003 tentang Kebijakan dan Strategi Nasional Pengembangan EGovernment 